\title{
Barriers to effective learning by university studentated learning: A case study of students on work related learning in Gweru urban area of Zimbabwe
}

\author{
Makuvaro Veronica $^{1 *}$, Ngara Rosemary ${ }^{2}$ and Magwa Simuforosa ${ }^{3}$ \\ ${ }^{1}$ Midlands State University, Department of Agronomy, Gweru-Zimbabwe; \\ makuvarov@msu.ac.zw / makuvarov@gmail.com \\ ${ }^{2}$ Zimbabwe Open University, Faculty of Education, Gweru-Zimbabwe; \\ rosemaryngara@gmail.com \\ ${ }^{3}$ Great Zimbabwe University, Department of Educational Foundations Masvingo-Zimbabwe \\ smagwa@gmail.com
}

\begin{abstract}
Work Related Learning (WRL) provides a platform for students to link theory and practice. Universities in Zimbabwe have WRL as part of their curricula and whilst some universities refer this programme to as "student attachment", others have adopted the term WRL. The period of student placement at work places may differ among universities. There has however, been a general move from short term periods to longer periods of attachment. When effectively carried out, WRL can benefit students, academic staff / institutions as well as the employer. The aim of this study was to identify barriers to effective learning of students on WRL. A case study was conducted with students on WRL in Gweru urban area. A questionnaire was administered to 50 students who were at 15 different workplaces during the period May-June 2014. Semi-structured interviews were also conducted with a total of eight co-ordinators of the WRL programmesat the Midlands State University in Gweru and supervisors at 12 randomly selected workplaces where students were seconded for the WRL programme. Problems encountered by students on WRL include delays in securing places for attachment, lack of financial incentives to meet basic requirements and limited access to Information Technology and Communication. The study recommends that Universities revisit their WRL programmes to address existing conditions, particularly those of large student numbers and a dwindling industrial base, that are rendering WRL less effective. Policies which permit effective placement and learning of students on WRL at both private and public work-places should also be put in place.
\end{abstract}

\section{Keywords}

Work related learning, students, barriers, revisiting of WRL programmes.

\section{Academic Discipline And Sub-Disciplines}

Education

\section{SUBJECT CLASSIFICATION}

Work-based learning

\section{TYPE (METHOD/APPROACH)}

Mixed research methods (quantitative \& qualitative); interviews

\section{Council for Innovative Research}

Peer Review Research Publishing System

\section{Journal: Journal of Social Sciences Research}

\author{
Vol. 7, No. 1
}

jssreditor.cir@gmail.com

www.jssronline.com 


\section{INTRODUCTION}

Work Related Learning (WRL) is a term that has been adopted by many educational institutions such as universities to refer to the type of learning whereby students spend part of their academic life seconded to some workplaces to gain work experience. WRL programmes are part of university curricula at most if not all universities in Zimbabwe and students are expected to be seconded to prospective workplaces for varying periods of time ranging from several months to as long as a full year. The timing of the WRL period is normally the period just prior to the start of the students' last academic year of study. When effectively implemented, WRL programmes can be beneficial to the students, academic institutions and the employer ([1],[2],[3]) when effectively implemented. For the students, the benefits may include enhanced employability particularly if the relationship between the employer and student is favourable 1] and development of both hard (for example data management and project planning) and soft ( for example, communication and social) skills (Mihail, 2006[4]; European [5]). WRL has also been found to improve academic performance of students [6],[7],[1].. On the other hand, WRL provides a source of employable graduates[3] for the employer and as highlighted [8], employers tend to recruit those students who have a working background. For most of these employers, the relatively cheap source of labour provided by students on WRL is an incentive for taking students for WRL [9]. Effectively organized WRL programmes enhance effective linkages / partnerships between universities and various orgainizations / industries as platforms for collaboration are created [2].

However, the outlined potential benefits, on the part of students, are sometimes not fully attained due to challenges that the students face while on WRL. Several researchers including 10], [8],; [11], [12] and [13] investigated the obstacles to effective learning by students on work-related learning. This study confirmed some of these obstacles for students from various Universities inZimbabwe, who were seconded to organizations in Gweru urban area during the period May-June 2014. Besides the commonly cited obstacles for example, difficulties in placement and lack of incentives, the study also looked at use of ICT by students, supervisor competences as assessed by students, mode of student assessment as understood / known by the students as well as relevance of the workplace's core-business and tasks assigned to the students. Students on WRL, workplace supervisors as well academic (university) supervisors were also engaged to provide suggestions for improving WRL programmes for university students.

\section{LITERATURE REVIEW}

This section provides a literature review on work related learning (WRL). It focuses on benefits and challenges of WRL.

\subsection{What is Work Related Learning?}

[14] define work related learning (WRL) as types of student employment experiences that are usually organized by their institution, related to their field of study and geared toward making connections between classroom learning and on the job experiences. WRL is a term covering activities that are intended to contribute to a student's fitness for employment [15]. From the above definitions it can be deduced that WRL refers to learning that occurs in a real working environment where students develop knowledge and understanding of the work. It can be described as a partnership among students, educational institutions and employers with each part having some specific responsibilities.

WRL can be any form of work or purposive activity that gives rise to learning. During WRL students can be paid. On the other hand WRL can be used only as a vehicle for learning rather than its perceived economic value. Thus students can be paid or unpaid [16]. WRL can last a year, a semester or a few days.

\subsection{Impact and Value of WRL}

There is a growing body of evidence to indicate substantial benefits of WRL in developing the capability of individuals and organizations. Through formal and informal interaction with colleagues, management and customers and by resolving real life challenges occurring at work students develop positive attitude toward work including taking responsibility, meeting deadlines and self efficiency [5]. One of the key strengths of WRL is that it is a very effective way to develop expertise skills and competences relevant to a given profession. [17] assert that as a result of work-related learning experiences students are able to manage time, believe in themselvesand work on theirown initiative.

According to [1] and [18] a major benefit of WRL is the increased employability of students. WRL helps students connect their learning with the world of work developing the employability skills that employers value. This matches well with the present trend whereby students expect a payoff from investment in education [19]. Students develop expertise not only through acquisition of technical skills and personal competences but also through socialization. [4] asserts that through WRL students are exposed to situations which assist them to develop interpersonal skills as conditions for socialization are provided. By interacting with peers and customers individuals gain a better understanding of the workplace's culture and develop good working habits [20]. Another benefit of WRL is staff retention. Companies know that offering learning opportunities is a way to retain staff [5]. Students who have trained with a company are more likely to stay with the employer because they feel a sense of loyalty and commitment.

\subsection{CommonlyCited Challenges that are Faced by Students on WRL}

[21] points out that basing learning around work is potentially limiting if the opportunity provided by the workplace does not form a good match to learners' aspirations. Qualified staff to supervise students may be in short supply. The learners may not be given the opportunity to demonstrate their capabilities and resolve problems in the workplace. [10] echo that staff who work directly with young people might not have the ability and may not be properly prepared to do so. Students 
are sometimes not given appropriate or specific tasks to expose them to proper job settings and experiences. In such a scenario self esteem and self efficiency will suffer.

Another hindrance to the success of the WRL program is the unavailability of places for students (http://www.aabri.com). Many students are facing challenges in securing places to do WRL. There are delays in securing the places and this can be as a result of countries experiencing high unemployment rates as a result of, for example, many companies closing down.

[12] and [13] are of the view that students are sometimes treated as providing cheap labour in organizations they will be attached to. They are treated as full time employees and despite this most of them do not get monetary rewards and this is quite a challenge.

\section{RESEARCH QUESTIONS}

i) What challenges hinder the smooth flow of the WRL programme?

ii) What measures should be taken to alleviate the problems encountered during WRL?

\section{PURPOSE OF STUDY}

The research aims to determine barriers to effective learning by university students on work related learning, with the aim of suggesting effective measures and solutions to these problems.

\section{RESEARCH METHODOLOGY}

\subsection{ResearchDesign}

A case study was conducted with students on WRL in Gweru urban area. The researchers employed the mixed methods research design. Mixed methods research is the type of research in which a researcher or team of researchers combines elements of qualitative and quantitative approaches (e.g. use of qualitative and view points, data collection and analysis, inference techniques) for the purpose of breadth and depth of understanding and corroboration [22]. Mixed methods research takes advantage of using multiple ways to explore a research problem. According to [23] the basic characteristics of the mixed methods research design are: design can be based on either or both perspectives, research problems can become research questions and/or hypotheses based on prior literature, knowledge, experience, or the research process, sample sizes vary based on methods used, and data collection can involve any technique available to researchers. According to Creswell as cited in [23] there are six mixed methods design strategies. In this study the researchers chose the concurrent triangulation mixed methods design strategy in which two or more methods are used to cross validate, confirm or corroborate findings within a study [23].The researchers chose the mixed research design for the merits it has. Using multiple approaches can capitalise on the strengths of each approach and offset their different weaknesses. So the mixed methods design was chosen because it is instrumental in overcoming limitations of a single design [22]).

\subsection{Sample}

Fifty students who were at 15 different workplaces during the period May-June 2014 were purposively and conveniently sampled for participation in the study. A total of eight co-ordinators of the WRL programmes at the Midlands State University in Gweru were also chosen by purposive and convenience sampling to take part in the study. Twelve randomly selected WRL supervisors were also included in the study giving a total sample of seventy participants (Table1).

Table 1: Number of Participants in the Study

\subsection{Instruments}

\begin{tabular}{|c|c|}
\hline Participants & Total \\
\hline Students & 50 \\
\hline WRL coordinators & 8 \\
\hline WRL supervisors & 12 \\
\hline Total & $\mathbf{7 0}$ \\
\hline
\end{tabular}

A questionnaire with both close ended and open ended questions was administered by the researchers to the students. The closed ended items had a set of responses from which the participants could choose the response they thought represented their opinion. Semi-structured interviews were also conducted with a total of eight coordinators of the WRL programmes at the Midlands State University in Gweru and 12 WRL supervisors. The questions on the interview guide were based on the research questions and they were both closed and open ended.

\subsection{Data Presentation and Analysis}

Data were presented qualitatively using thick descriptions and quantitatively using some enumerative statistics, tables and figures. Data were analysed across respondents in relation to the objectives of the study. 


\subsection{Limitations}

Since this study is specific to Gweru urban, it is highly likely that it will indicate some issues about practices and opinions of students, WRL coordinators and WRL supervisors on work related learning in Gweru urban area only. As the study just involved participants from Gweru urban findings may not be generalised to other places where students are attached for work related learning. Notwithstanding, the picture may be a replica of what obtains in the minds of students, WRL coordinators and WRL supervisors elsewhere in university education.

\section{RESULTS AND DISCUSSION}

\subsection{DemographicData}

Of the 50 students interviewed, $48 \%$ were females and $52 \%$ males. Sixty eight percent of the students had Gweru urban as their usual place of residence (during vacations) while the remaining $32 \%$ normally resided elsewhere in Zimbabwe, (outside Gweru urban). Seventy six percent of the students were aged $20-25$ years, while $24 \%$ were between 26 and 30 years of age.

The students interviewed were from five universities comprising four state universities and one private university. The organizations to which they were seconded for the WRL programme included seven government institutions, four parastatal organizations, three private institutions and one non-governmental organization (NGO). The majority of the students (60\%) were seconded at government institutions, $22 \%$ at parastatals, $12 \%$ at private organizations and $6 \%$ at a NGO.

\subsection{Challenges Faced By Students on WRL}

\subsubsection{SecuringPlaces for Work-Related Learning.}

The findings of the study revealed that $58 \%$ of the students secured places for WRL after two months from the time they completed their preceding academic year (Figure 1). Two months is about the duration of the vacation period for the universities at which the students interviewed were enrolled. Thus, it was assumed that students who secured places within a period of two months would normally meet the required duration of secondment at WRL places. About $18 \%$ reported that they secured places within one month, 24\% after 3-5 months and none after five months (Figure 1). According to the findings, the majority of students $(78 \%)$ sourced places for WRL on their own through written applications, while $18 \%$ did so through influential relatives and only two students acknowledged assistance from their university academic Departments. All the students who were assisted by relatives in influential positions started their WRL programmes within two months after completion of their preceding academic year of study. Although only two students indicated that they secured WRL places through their university academic Departments, most university academic regulations indicate that academic Departments would normally assist students get places. These results show that it is relatively difficult to secure placement of students for WRL purposes. This can be attributed to increasing number of universities and student enrolment over the years, in an environment where the industry base is dwindling both in number and scale of operation. Similar findings were reported by [24] who noted that placement of students for WRL was a problem in Zimbabwe, Ghana and Nigeria as employers were reluctant to take on students. [13] [8] and [25] also established that student placement was a constraint at universities where theycarried out their research in Zimbabwe.

Four of the organizations where some of the interviewed students were seconded confirmed that they normally recruited students for WRL only once a year, at the beginning of the year. They would however,,sometimes take students in the middle of the year (from Universities that have two intakes per year) to at least help the desperate students meet their requirement of spending a specified period at some relevant work place. Such students would, however, not get any remuneration since budgets were done only ones a year prior to start of year.

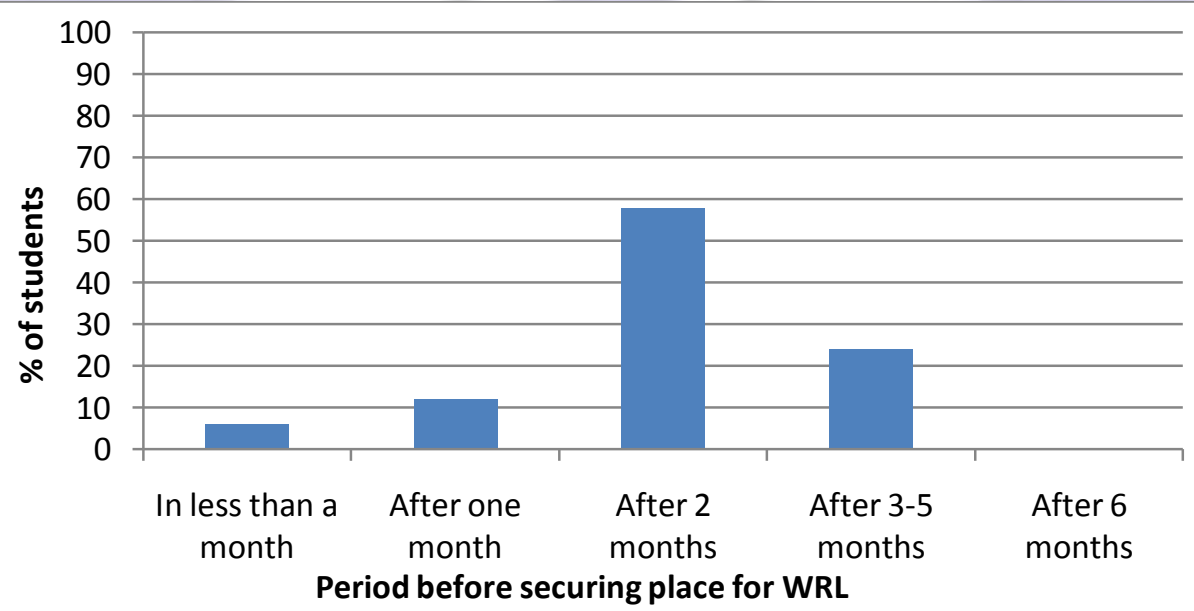

Figure 1: Period taken by students to get places for WRL after completing the 
academic year preceding the WRL level

\subsubsection{Relevanceof Organizations' Core-Business to Students' Study Programmes}

Brown (2002)[9] reckons that "placements in which the work relates directly to the course being studied bring the knowledge alive". Such placements also "inform the curricula and keep those in higher education up to date with current business" (Brown, 2002)[9]. Sixty two percent of the students interviewed in this study confirmed that the core-business of the organizations to which they were seconded for WRL was quite relevant to the programmes they were pursuing at university. However, for $32 \%$ of them, the core-business was relevant to a limited extent and $6 \%$ of the students ascertained that there was no match at all between the two (Figure 2a). Reasons for the mis-match included failure by students to get placement at the most relevant organizations. Some of the students could not take up WRL places outside Gweru urban, their usual residential place, to avoid high living expenses associated with staying away from home. Some students felt that at times they were not trusted to perform certain tasks by the employers, thereby making the workplace core-business seemingly less relevant to them.

About two-third of the students acknowledged being assigned to do tasks that were related to work, while about a third reported that tasks assigned to them were not always job-related as they had to attend to their managers' private businesses on several occasions (Figure $2 \mathrm{~b}$ ). The non-job related tasks included paying bills (electricity, water and owners' rates) and buying food items (lunch) for the managers, while others had to write assignments for their mentors who were studying at local universities in Gweru urban. These findings are in agreement with [8] who highlighted that sometimes employers do not provide students with all the necessary skills and that students end-up doing menial tasks in some cases. This discourages effective learning by students. However, while the students may have limited capacity to rectify the problem, it becomes imperative for students to try and plan their work in such a way that they still achieve their WRL goals.

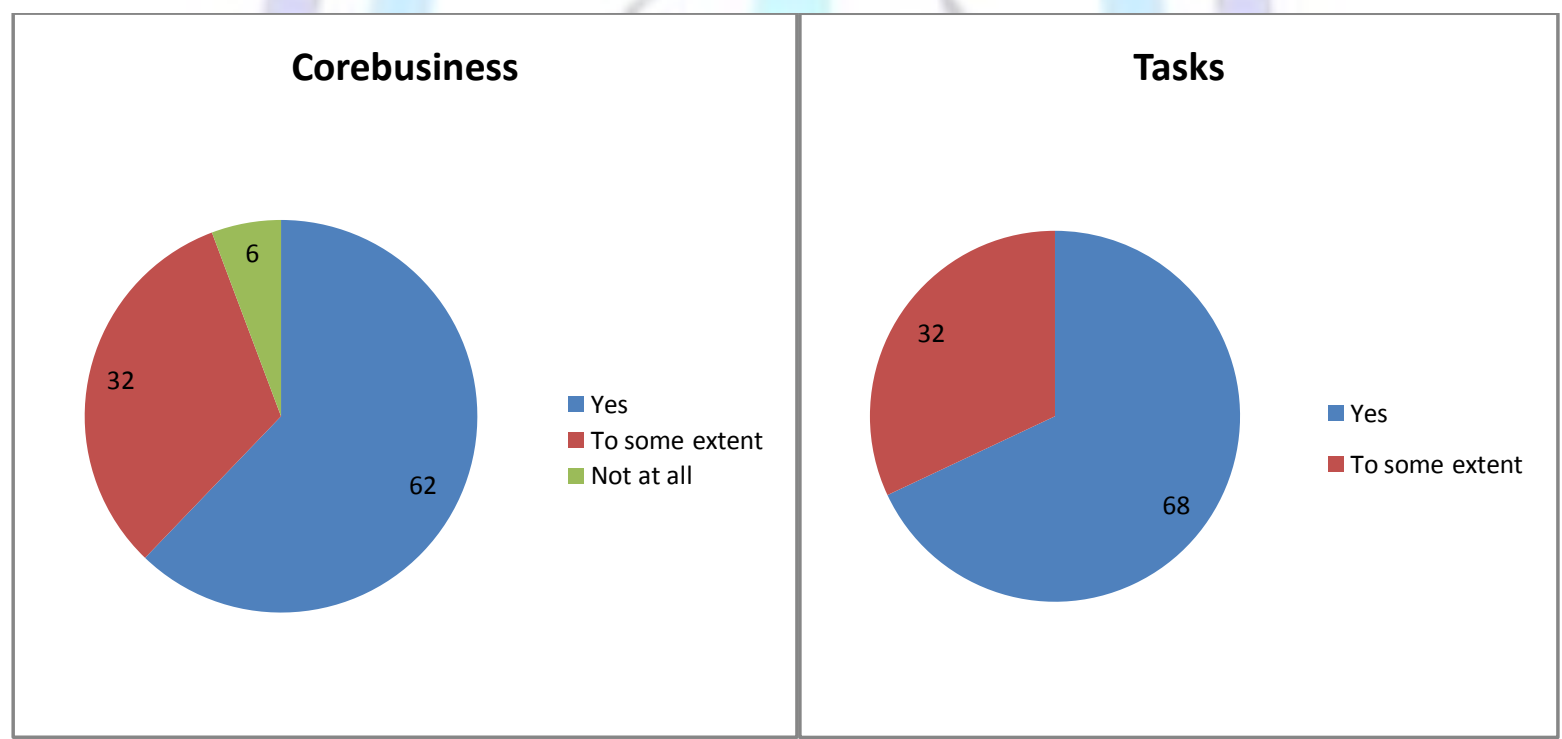

Figure 2. Percentage of students who agreed or disagreed that a) core business of the WRL organization was related to their university programmes and b) the tasks allocated to them were work-related

\subsubsection{Student Assessment}

Assessment is done so that students earn an academic credit for WRL experiences [11]. Responses from students showed that diverse methods were employed by universities and faculties to assess students on WRL. The methods evolve around WRL and university supervisors as well as students' reports (Figure 3). Majority of the students (43\%) indicated that they were assessed based on a combination of their lecturers and mentors reports as well as their own reports which were submitted to their academic Departments. About $17 \%$ of the students indicated that in addition to the three afore-stated reports, a research project carried out during the WRL period also constituted the WRL assessment. However, on further probing using desktop study, it was established that although these students did research projects during the WRL period, these projects were only considered for their final year assessment. ( It should however be noted that there are some universities/ programmes in the country excluding those from which the students in this study were drawn, which require that students carry out mini projects for which they are assessed for their WRL level). The remainder of the students indicated that they were assessed on combinations of reports indicated in figure 3. Although only one student indicated that she was not sure of the basis of the assessment (Figure 3), it became apparent that few other students were not aware of what they were assessed on, particularly those that said they were assessed based on either their own or the supervisors' reports only. Most university academic regulationsspell out the basis for assessing students on WRL, hence one would expect students to be fully aware of the assessment criteria.. The regulations also stipulate the relative contribution of these modules to the overall Degree Class. 


\section{ISSN 2321-1091}

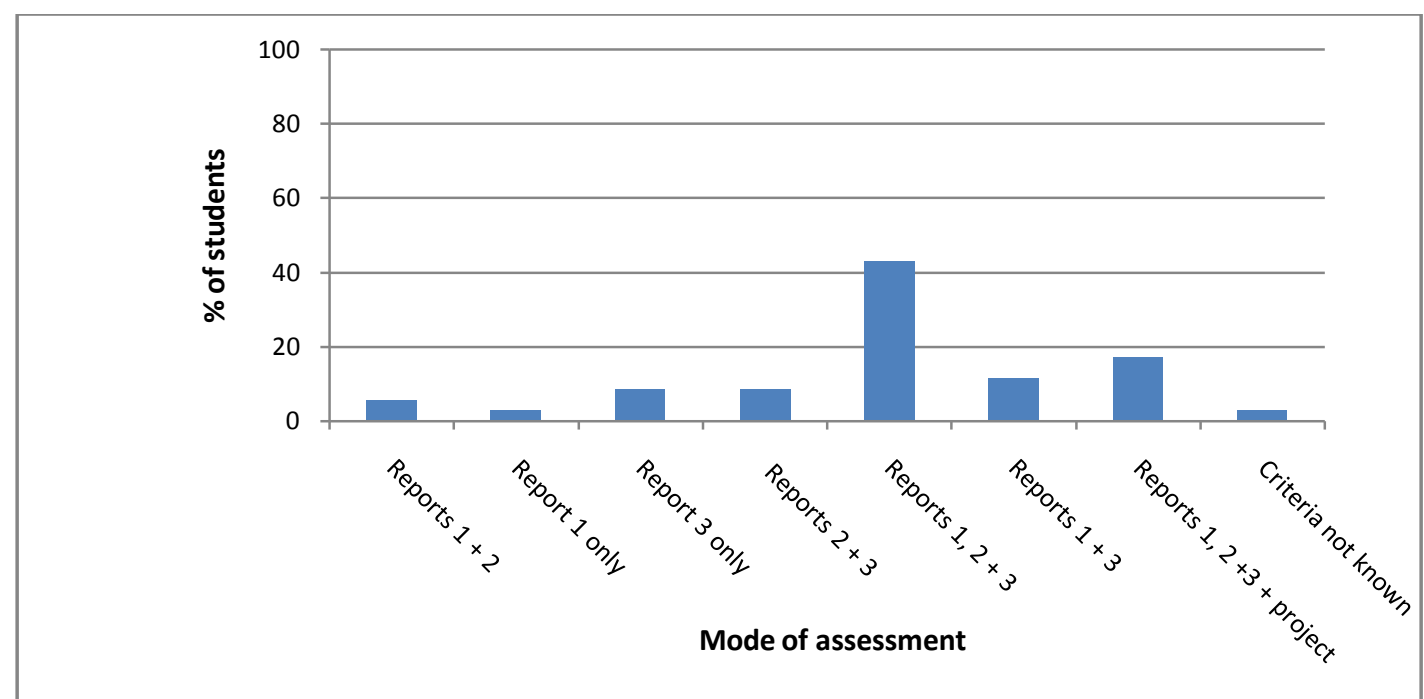

Figure 3. Modes of WRL assessment of University students on WRL in Gweru urban in June 2014

Key: Report 1= student report; Report 2 =WRL supervisor report; Report 3= Academic supervisor report

There are variations in the weight given to WRL modules among universities and programmes, with most universities which have a full year devoted to WRL, giving these modules a weight of $20-30 \%$ of the overall degree class. Thus, the WRL module(s) contribute significantly to the student's Degree Class. Thus it is pertinent that students are sure of the assessment criteria used by their universities.

\subsubsection{ResearchProjects During the WRL}

Forty percent of the students were doing research projects during the WRL period and it was encouraging to learn that these students had identified project topics on their own. It is, however, not uncommon for WRL and university academic supervisors to identify research topics for students. For one of the universities at which students interviewed were enrolled, it is mandatory that students do a research project while on WRL, although the project is a final year (year following the WRL year) module. However, for the other four universities, students were not obliged to carry out the research project during the WRL period, but were only encouraged to do so. A research project is also a final year module for these universities.

\subsubsection{Use of Information and Communication Technology (ICT)}

Eighty eight percent of students used ICT at their WRL places and the main ICT tool used was the computer (Figure 4). Other ICT tools used included Internet Protocol (IP)-based phones, cellphones and tablets. ICT was used mainly for report writing, data processing and to a lesser extent database management (Figure 5).According to the students, the major barriers to use of ICT was lack of ICT tools, followed by lack of training on the part of users and resistance to change by some employers as they were reluctant to adopt improved technology. Instead, thes employers resorted to old systems of data processing and database management (Figure 6). Incompetence on the part of ICT service providers and old desktops were also cited as barriers to use of ICT in some organizations. At one private institution, there was only one computer from which internet services were accessed and a student seconded to this organization had the privilege to use this computer. The student was, however, overwhelmed by the need to attend to all e-mails of managers as she had to access their emails and respond to all of them.

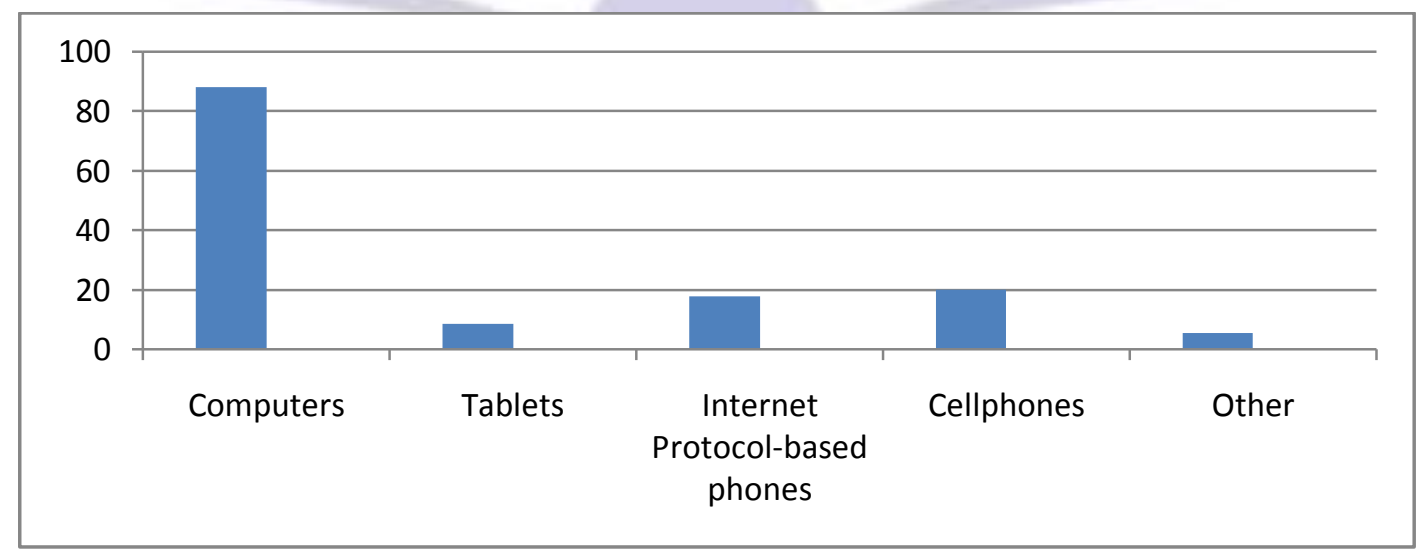

Figure 4. ICT tools used by university students on WRL at different organizations in Gweru urban as at May-June 2014. 


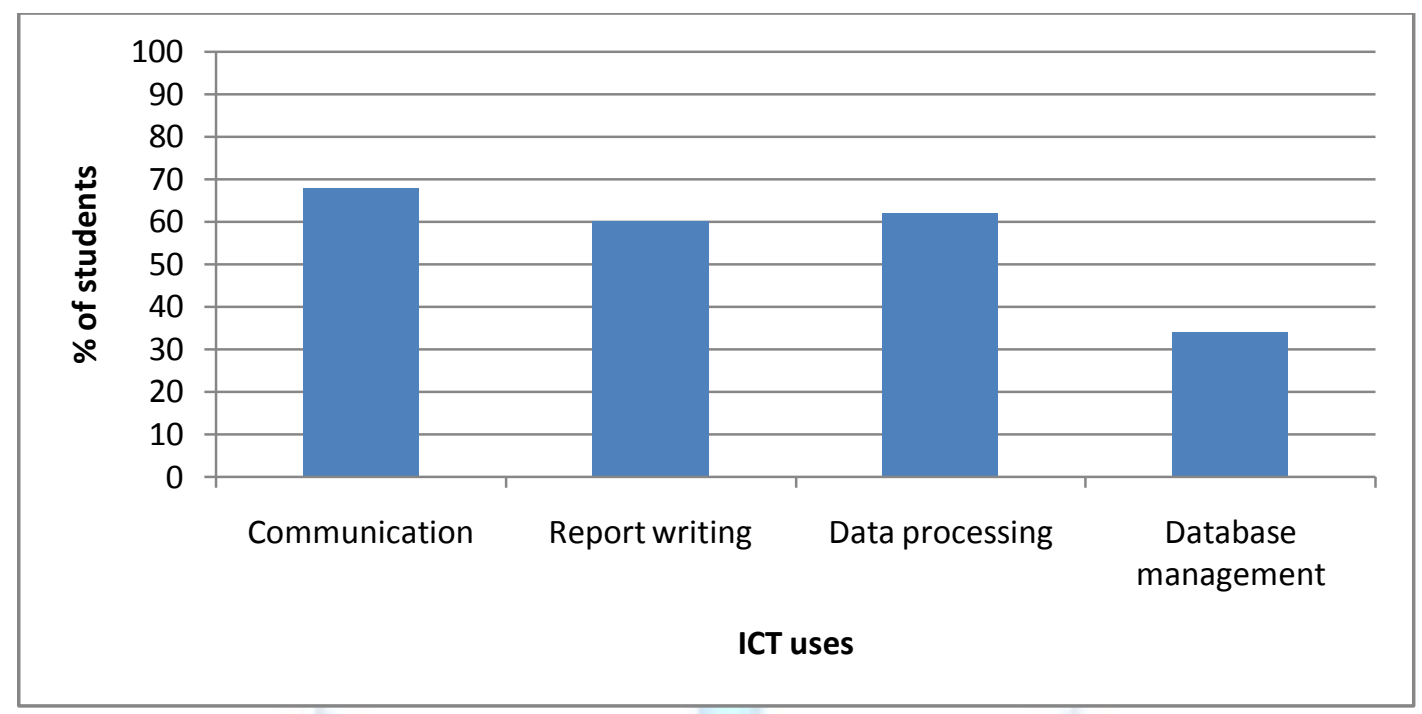

Figure 5. Uses put to ICT by university students on WRL in Gweru urban during May-June, 2014

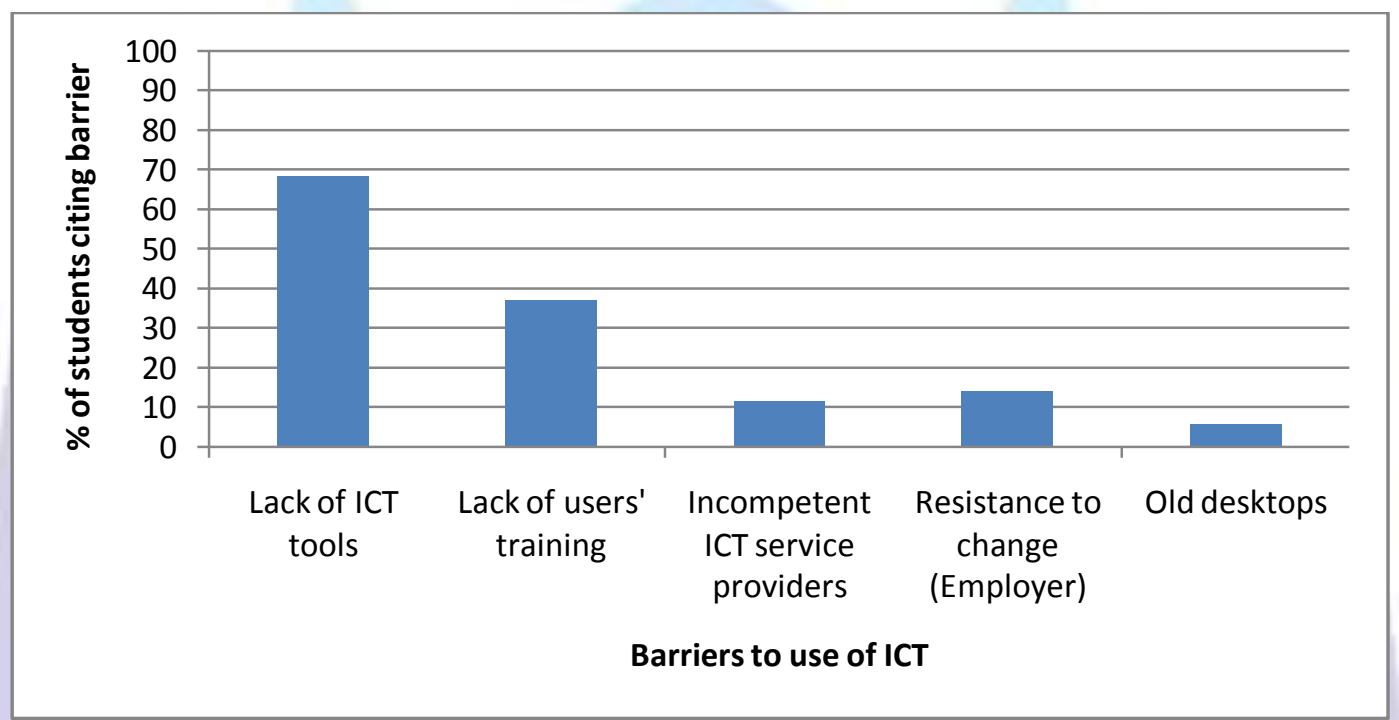

Figure 6. Barriers to effective use ICT by students on WRL in Gweru urban during May-June, 2014

Free access to ICT is important in skills development which is an integral part of WRL programmes [11]. Thus, any challenges of access to ICT at workplaces are of great concern. Although several barriers to use of ICT were identified by students, it was encouraging to note that the majority of them had access to the basic IT tool, the computer. Challenges of access to ICT at workplaces can be attributed to factors such as difficulties faced by organizations to acquire all necessary equipment to keep pace with the continuous change in technologies (Bottoms and Mcnally, 2008)[26]. According to [11] firms are sometimes reluctant to grant free access to ICT. Attitudinal problems, on the part of the employers are also embedded in the observation made by students (in this study) at certain workplaces that some employers are reluctant to take up and use new technologies. Findings of this study have indicated the need for training of ICT users at workplaces as well as that of service providers.

\subsubsection{IncentivesReceived by Students on WRL}

Other than acquiring knowledge and skills, $74 \%$ of the students got some form of incentive while $26 \%$ did not get any form of incentive. About half the students got financial benefits in the form of monthly payments and / or for travel and subsistence expenses when they went out of Gweru urban on official duty. Thirty four percent got free food (either tea and / or lunch). Other benefits received by students were free medication for those who were seconded at health institutions and transport to and from work for some of those seconded to Government institutions (Figure 7a).

Thirty percent of the students acknowledged the high level of personal and social competencies they had attained while on the WRL programme. They indicated that they had greatly improved on aspects such as communication skills, team working and decision making. This finding concurs with [5] and [4] who established that besides acquiring workplacerelevant skills (hard skills) and competences, students on WRL also acquired personal and social skills such as taking responsibility, budgeting and interpersonal skills. Students who were seconded to one of the parastatal organizations and to an NGO, had received T-shirts which were used in campaign programmes to promote certain agendas and activities of the organizations within and outside Gweru urban. 
Financial benefits were within the range less than 100 USD to 200-300 USD (Figure 7b). It was noted that at two of the institutions that provided financial benefits to students, some of the students received this benefitwhile others did not. Those who were not paid had volunteered to go unpaid and the reason why employers could not pay them was that they did not have a budget for these students as they had joined the organization in the middle of the year. Thus, with the fully semesterized system (where there are two intakes per year), implemented at some universities, students who go for WRL during the middle of the year will not normally receive remuneration at some work places. In general most organizations said they had a limited budget for the WRL programmes. In Gweru urban, the number of prospective employers had also gone low at the time of the interviews as some big industries had either shut down or down-scaled their operations and this forced some students to go for WRL at work-places where no remuneration was offered.
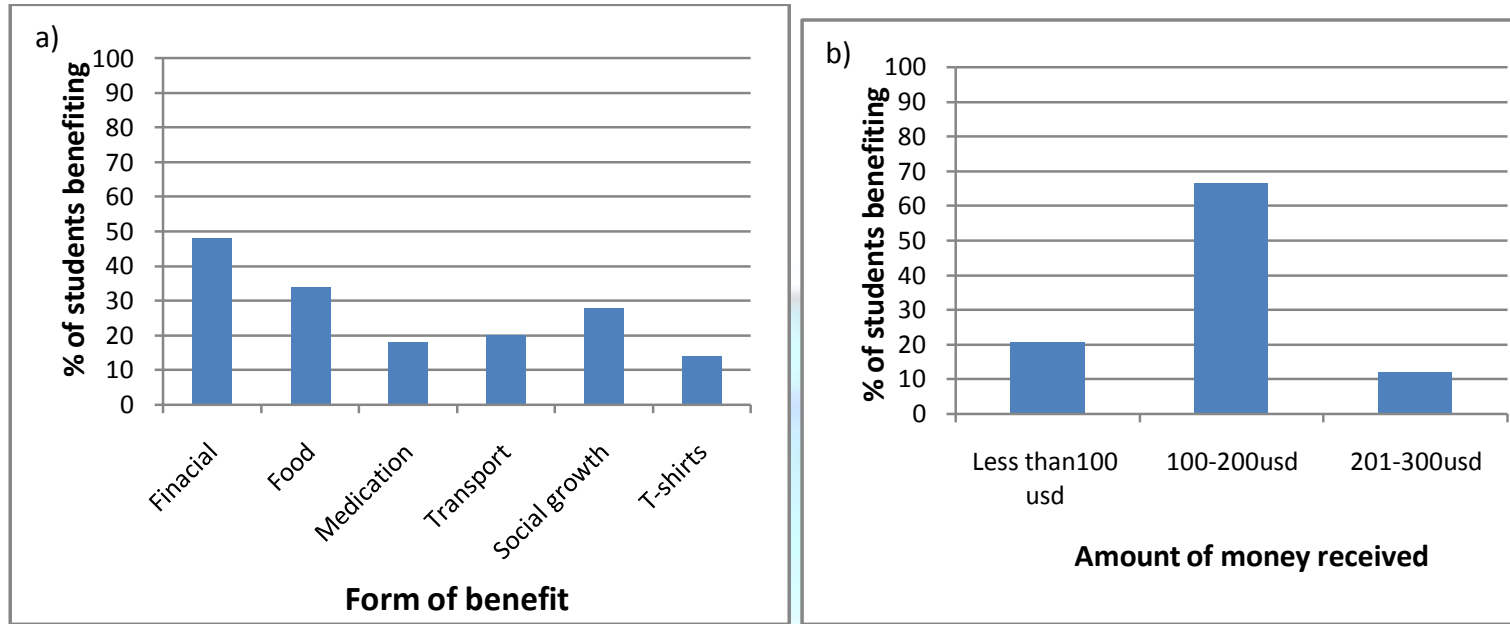

Amount of money received

Figure 7. Benefits received by university students on WRL in Gweru urban as at June 2014

Results of this study show a wide spectrum of benefits that students on WRL in Gweru urban receive. However, such benefits are only limited to few students. Lack of incentives has also emerged as an area of greatest concern according to studies carried out on constraints faced by students on WRL in Zimbabwe and other countries [12], [11],,[13]). In a study carried out on problems faced by Zimbabwe Open University students on WRL, 25] found that $80 \%$ of the participants agreed that non-payment was a major problem. The students interviewed also pointed out that they provided a cheap source of labour. These findings are consistent with findings of this study in that majority of students were not paid and those who were paid, received relatively low remuneration. In a separate study, [13] also reiterated the treatment of students on WRL as a cheap source of labour, while [11] pointed out that students on WRL were not compensated for transport.

\subsubsection{WRLSupervisors' Competence}

Approximately $66 \%$ of the students reported that their WRL supervisors were first degree holderswhile $14 \%$ and $6 \%$ of them had supervisors with diplomas and certificates, respectively. The remaining $14 \%$ were not sure of the academic qualifications of their supervisors. Academic qualification of the mentor is important as it is likely to determine the level of knowledge and skills the student may acquire during the WRL period. Workplaces need qualified supervisors who can create and manage learning environments where students can prepare for success (Bottoms and Mcnally, 2008)[26]. It was pleasing to note that the majority of students (more than $85 \%$ ) indicated that their WRL supervisors were competent in use of computers, in mentoring and motivating them as well as in communicating with them (Figure 8). However, about half the students, were not sure whether their supervisors effectively communicated with the universities where they were enrolled. The various skills are important as they facilitate effective learning by students.

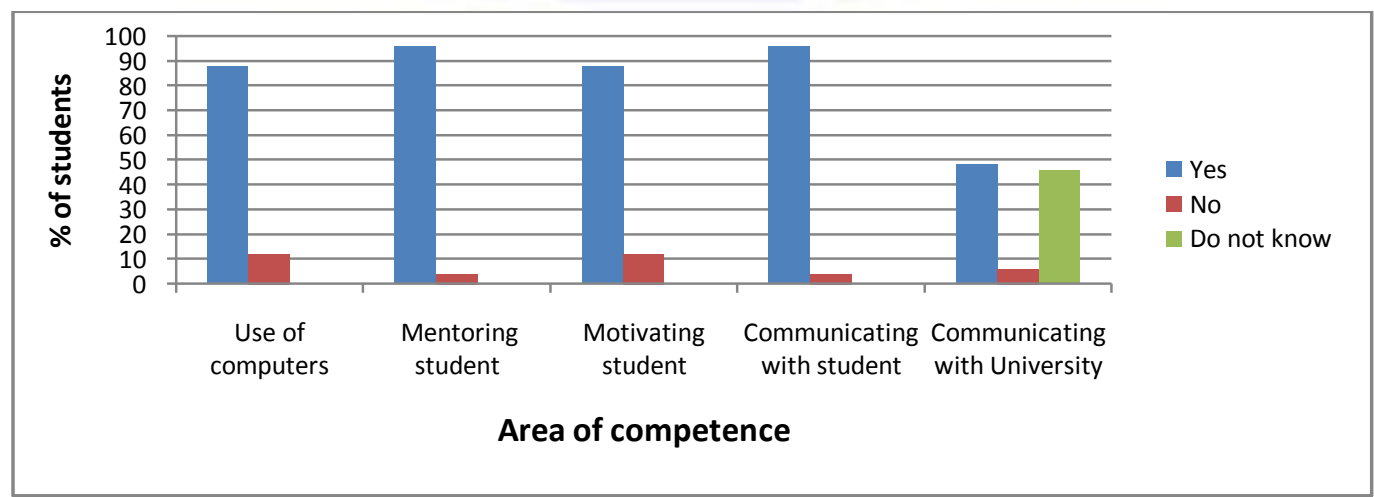

Figure 8. Competence of WRL supervisors at organizations in Gweru urban, where some university students were seconded as of May and June, 2014 


\subsection{Suggestionsby Students, WRL Supervisors and University WRL Co-ordinators for Improving Conditions of Students onWRL}

Of the 50 students interviewed $46 \%$ suggested that universities be involved in securing appropriate WRL places for students as these were difficult to get. The students pointed out that this was particularly true for those students who had to start WRL programmes in the middle of the year. Similar sentiments were given by WRL supervisors and co-ordinators ofWRL programmes at Midlands State University in Gweru.. Most WRL supervisors indicated that their organizations could only take a limited number of students per year due to budgetary constraints, while university WRL co-ordinators mentionedthat it used to be relatively easy to find placement for students, when student numbers were low and when few universitiessent their students for WRL for long periods. They also attributed the difficulties in student placement to the closure and / or down-sizing of several industrial companies in Gweru urban. For universities with two intakes per year, one group of students would needto get seconded for WRLwhile the students from the preceding group are still at the WRL places. This, according to some WRL coordinators further compounded the problem of student placement. The study revealedthat students were quite concerned about payment of fees during the WRL period, with $36 \%$ of them suggesting thatstudents should either not pay any fees or the fees be reduced, for example by $50 \%$. They felt that universities did nothave much expenditure on the WRL programme as some of the students were only visited ones by their academic supervisors.

Most students expressed disgruntlement over lack of incentives from the employers. They expected to get at least an allowance to cater for transport and food while at the workplaces. They suggested that universities or government should give grants, to students seconded atworkplaces where no financial benefits were provided. WRL supervisors sympathised with the students and said their reasons for limited or no financial support of the students was constrained budgets.

One important suggestion made by the students was reduction of the WRL period from the current 8-12 months (for most universities) to about half this duration. For most universities the suggested duration would be equivalent to a semester. Reasons for this suggestion included the difficulties in securing placement and financial challenges faced by students during the WRL period. On the contrary, most WRL co-ordinators and supervisors at workplaces advocated for maintenance of the current duration of the WRL programme as this would give the students ample time to acquire workrelated knowledge and skills.

Some students felt that there was limited communication between the university and students on WRL. They, thus, suggested regular communication and support, as well as increased frequency of visits by academic supervisors. According to WRL coordinators, two visits were normally made to the students where the first visit was done within 2-3 months of placement to supervise and guide the student. The second visit was ear-marked for the period towards the end of the WRL period and was meant to assess the performance of the student while on WRL. Due to the large number of students that had to be visited and the distances covered to get to the different WRL places, coordinators indicated that it wasunlikely that students would be visited more than twice. They also indicated that in some, though rare instances students were visited only once.

Other suggestions made by students included the need by employers to use modern technology (ICTs) to perform tasks such as data processing and management as well as report writing. Organizations also needed to acquire state of the art equipment for practical - oriented disciplines such as surveying to enhance skills acquired by students and ease tasks given to them. On the other hand, some students thought that their university programmes lagged behind in the curricula they offered as much more was offered at the workplace. Some students proposed that research projects be done during the WRL programme. These students were those from universities where it is not compulsory for students to do a research project during WRL. This would increase the chances of students to embark on relevant research topics and give them ample time to work and finish their projects. This would also strengthen the relationship between universities and industries as the students were likely to carry out their research at the WRL places and were likely to be co-supervised by both the university and WRL supervisors. Students also looked forward to their employers to provide jobs or link them to other prospective employers to increase their chances of getting employment. Some also proposed to change WRL places during the WRL period to expose them to different working environments.

\section{CONCLUSION}

The study established major constraints faced by students on WRL in Gweru Urban area. It also quantified the extent to which these constraints affected the students, in terms of the numbers affected. The study confirmed some of the constraints that have been identified in other studies involving students from selected universities in Zimbabwe and other countries and has generated fairly new information in other areas like use of ICT as well as assessment of relevance of the workplace core-business (to students' academic programme) and supervisor competence. Interviews with WRL university (Department level) co-ordinators and WRL supervisors (employers) showed that the constraints faced by students are not only of concern to the students, but also to the universities and to the employers. The study also provided 
avenues for improving conditions of students on WRL through dialogue with key stakeholders, the students, university WRL co-ordinators and WRL supervisors.

\section{RECOMMENDATIONS}

Based on the findings of this research, the following recommendations are made:

The challenges faced by students on WRL, particularly those related to placement and lack of incentives require that universities re-visit the current WRL programmes and identify ways to ensure sustainability of the programmes. Difficulties in securing WRL places, which has intensified in recent years, may call for a revision of the WRL duration and alternative ways of providing the much needed work-related experience. To this effect researchers recommend strategies such as placement of students on community based projects which are spear-headed by their universities as well as selfemployment, for students who have been trained and equipped with entrepreneurship skills. Such ideas are already being implemented by one of the State universities in the country, the Midlands State University, on a programme they term "Community Engagement". Universities could also consider placing students at organizations on rotational basis and in groups for specified periods of time. This approach would ensure that all students get relevant work-related learning experience and would also provide diverse work-related learning experiences for students. Universities may also consider re-visiting timing of the WRL programme: Instead of having WRL being strictly being confined to the year prior to their final year, students could also go for WRL after completing the taught levels, but would only graduate after meeting the WRL requirement. Guidance and assistance in securing WRL placements by universities academic Departments to which students are enrolled would also ensure placement of students at relevant institutions.

Governments and / or universities should consider providing grants or allowances to students on WRL. It may be necessary to put in place policies that enforce appropriate placement of students. Financial facilities such as the Zimbabwe Manpower Development Fund (ZIMDEF) which currently benefits only students from Poly-technical Colleges could be set up to assist university students as well. It may also be necessary for universities to revise fees structures for the WRL year: some of the fees could directly benefit the student while on WRL.

We recommend that research projects (which are mandatory at most if not all universities in Zimbabwe) be carried out starting during the WRL level, irrespective of the year when the research module is considered for assessment. Universities should constantly update their curricula to match industrial needs, while the various industries should employ modern technology in running their programmes and activities to enhance learning by the students. Supervisors at WRL places are also encouraged to enhance student learning by ensuring that they, to a large extent, assign students tasks relevant to work.

\section{ACKNOWLEDGEMENTS:}

We are grateful to the students, WRL supervisors at the 15 institutions at which interviewed students were seconded and Midlands State University WRL coordinators for providing their views and sharing their experiences on universities WRL programmes. Thanks also go to the managers at the various work places for giving us permission to interact with the students during working hours.

\section{REFERENCES}

[1] Mendez, R. 2008. The correlation between industrial placements and final degree results: A study of Engineering Placement Students. University of Leicester- Retrieved on 22/01/15 from: http://aces.shu.ac.uk/employability/resources/CorrelationBetweenPlacementsandFinalDegreeResults.pdf

[2] Stanbury, D., Williams, H. and Rees, J. 2009. Engaging employers to enhance teaching and learning: Ideas and approaches for work related and placement learning. Reading University, UK. Retrieved 24/01/2014 from: http://www.reading.ac.uk/web/FILES/ccms/B02056 Employment Engagment AS V6.pdf

[3] Holzer, H.J. and Lerman,R.I. 2014. Work-Based Learning to Expand Jobs and Occupational Qualifications for Youth . Washington DC. Retrieved on 22/01/12 from: http://www.pathtofullemployment.org/wpcontent/uploads/2014/04/holzerlerman.pdf

[4] Mihail, D.M. 2006. Internships at Greek universities: An exploratory study. J. Workplace Learn. 18(1), 28 - 41.

[5] European Training Foundation (2013). Work-based learning: Benefits and obstacles: A literature review for policy makers and social partners in ETF partner countries. European Commission 2013. Available on: http://www.etf.europa.eu/webatt.nst/0/576199725ED683BBC1257BE8005DCF99/\$file/Workbased\%20learning Literature\%20review.pdf. Accessed 13/11/2014)

[6] Gomez, S., Lush, D. \& Clements, M. 2004. Work Placements Enhance the Academic Performance of Bioscience Undergraduates, J.Vocat. Educ. Train. 56 (3), 373-386. Retrieved on 15/11/2014 from: http://heer.qaa.ac.uk/SummaryPDFsRestricted/LTA33.pdf

[7] Confederation of British Industry, 2009. The Role of Work-integrated Learning in Academic Performance: Is there correlation between industrial placements and degree performance?:Confederation of British Industry Higher Education Task Force. Retrieved on 22/09/14 from: http://www.waceinc.org/hongkong/linkdocs/papers/UK/Refereed\%20Paper\%203.pdf

[8] Matamande,W. Nyikahadzoi, L., Taderera, E. and Mandimika, E. 2008. An investigation of the effectiveness of work related learning: A case of the industrial program offered by the Faculty of commerce, University of Zimbabwe. J.Instr.Pedagog.Retrieved 20/01/2015 from: http://www.aabri.com/manuscripts/131524.pdf

[9] Brown, R (2002). Work related learning “. Report commissioned by the Department for Education and Skills in November 2000. Retrieved on 24/01/2014 from http://tna r.europarchive.org. 
[10]Lam, T. and Ching, L. (2006). An exploratory study of an intership program: The case of Hong Kong students. Hosp.manag. 26,336-351.

[11] Donkor, F., Nsor, S.N. and Mitchpal, S.J. (2009). Assessment of supervised industrial attachment of a technical and vocational teacher education program in Ghana.Asia-Pacific. J. Coop. Educ. 10 (Jan. 2009), 1-17. Retrieved on 28/01/2015 from http://www.apjce.org/files/APJCE_10_1_1_17.pdf

[12] Bukaliya, R. 2012. The potential benefits and challenges of internship programmes in ODL institution: A case for the Zimbabwe openUniversity.Int.J.NewTrends.Educ.Implic. 3 (Jan. 2012), 118-133.

[13] Munzara, A., NhamoMashavira, N. and Mtemeri, J. (2014). Confronting the challenges bedevilling work related learning at a selected university in Zimbabwe: Mentors' perspectives. Int. J. Engl.Educ. 3 (Apr. 2004), 585-593.

[14] Kramer, M. and Usher, A. (2011). Work integrated learning and career-ready Stvs: Examining the evidence .Retrieved 20/12/2014 from http:higheredstrategy.com.

[15] Knight, P.T. and Yorke, M. (2004). Learning, curriculum and employability in higher education. London: RoutledgeFalmer.

[16] Lester, S. and Costly, C. (2010). Work-based learning at higher education level: value, practice and critique. Stud.High.Educ. 35(5), 561-575. London: Middlesex University.

[17] Gill, A. and Lashine, S. (2003). "Business education: a strategic market-oriented focus", Int.J.Educ.Manag. 17 (July, 2003),188-194.

[18] Day, H (2010). Work related learning in English studies: A good practice guide. The higher education academy.Landshire.

[19] Abeysekera, I (2006). Issues relating to designing a work integrated learning program in an inadequate accounting degree program and is implications for the curriculum Retrieved on: http://www.apjce.org.Accessed 24/09/14.

[20] Brennan, L. (2009). Integrating work-based learning into higher education: A guide to good practice.Bolton: University Vocational Awards Council.

[21] Zembylas, M. 2006.Work -based learning, power and subjectivity: Creating space for a foucauldian research ethic. J.Educ.Work, 19(Jul.2006), 291-303.

[22] Angel, B. and Townshed, L (2011). Designing and conducting mixed methods studies. Workshop for the 2011 society for social work and research annual meeting. Retrieved 22/09/2014 from:http://www.sswr.org/Designing\%20and\%20Conducting\%20Mixed\%20Methods\%20Studies.pdf

[23] Biddix, J.P. ( undated). Mixed research designs. Retrieved 22/09/2014 from http://researchrundowns.wordpress.com/mixed/mixed-methods-research-designs/

[24] Afonja, A.A., Sraku-Lartey, K. And Oni, S.A (2005). Engineering education for industrial development: Case studies of Nigeria, Ghana and Zimbabwe. ATPS working paper No. 42. Nairobi Kenya: The African Rechnology Policy Studies Network. Retrieved on 28/01/2015 from www.atpsnet.org/filed/working paper 42pdf.

[25]Rupande, G and Bukaliya, R. 2013. Challenges of integrating work related learning among open and distance learning students at the Zimbabwe Open University. Int. J. Adv. Res.1(Dec. 2013), 658-668.

[26] Bottoms, G. And McNally, K. 2008. Actions states can take to place a highly qualified career / technical teaching in every classroom. Atlanta, GA: Southern Regional Education Board. Retrieved on 28/01/2015 from http://www.sreb.org/page/1252/publications.html

\section{Author' biography with Photo}

\section{First \& corresponding author :Dr Veronica Makuvaro.}

Academic Qualification: PhD in Agricultural Meteorology

Profession: Lecturer (Midlands State University - Department of Agronomy, Zimbabwe)

Second Author: Mrs Rosemary Ngara

Academic Qualification: Masters Degree in Curriculum Studies; Currently a PhD student with the Zimbabwe Open University

Profession: Lecturer (Zimbabwe Open University - Department of Education)

Third Author: MrsSimuforosaMagwa

Academic Qualification: Masters Degree in Educational Psychology; Currently a PhD student with University of South Africa UNISA

Profession: Lecturer (Great Zimbabwe University - Department of Education, Zimbabwe) 